\begin{tabular}{|c|c|c|}
\hline & Int.J.Curr.Microbiol.App.Sci (2021) 10(09): 578-585 & \multirow{4}{*}{ 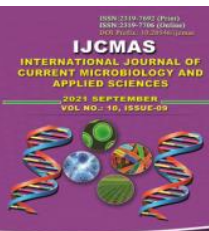 } \\
\hline & \multirow{4}{*}{$\begin{array}{l}\text { International Journal of Current Microbiology and Applied Sciences } \\
\text { ISSN: 2319-7706 Volume } 10 \text { Number } 09 \text { (2021) } \\
\text { Journal homepage: } \underline{\text { http://www.ijcmas.com }}\end{array}$} & \\
\hline & & \\
\hline $\begin{array}{l}\text { EXCELLENT } \\
\text { PUBLISHERS }\end{array}$ & & \\
\hline & & www.ijemas.com \\
\hline
\end{tabular}

\title{
Land Use/Land Cover Mapping of Sambar Watershed by Using Remote Sensing and GIS
}

\author{
B. Varpe Shriniwas* and D. Payal Sandip \\ Department of Soil and Water Conservation Engineering, CAET, \\ VNMKV, Parbhani, M.S., India \\ *Corresponding author
}

\section{A B S T R A C T}

Keywords

Land use/Land

Cover, Remote

Sensing,

Geographical

Information System

Article Info

Accepted:

25 August 2021

Available Online:

10 September 2021
In the present study, an effort has been made to study in detail of Land Use/Land Cover Mapping for Sambar watershed by using Remote Sensing and GIS technique was carried out during the year of 2020-2021 in Parbhani district. In this research the Remote Sensing and Geographical Information system technique was used for identifying the land use/land cover classes with the help of ArcGIS 10.8 software. The Sambar watershed is located in $19^{\circ} 35^{\prime} 78.78^{\prime \prime} \mathrm{N}$ and $76^{\circ} 87^{\prime} 88.44^{\prime \prime} \mathrm{E}$ in the Parbhani district of Marathwada region in Maharashtra. It is covered a total area $97.01 \mathrm{~km} 2$. The land use/land cover map and its classes were identified by the Supervised Classification Method in ArcGIS 10.8 software by using the Landsat 8 satellite image. Total six classes are identified namely as Agricultural area, Forest area, Urban area, Barren land, Water bodies and Fallow land. The Agricultural lands are well distributed throughout the watershed area and it covers 4135 ha. (43 per cent). Forest occupies 502 ha area and sharing about 5 per cent of the total land use land cover of the study area. The Urban land occupies 390 ha. area (4 per cent) and there was a rapid expansion of settlement area. Barren land occupies 3392 ha. area (35 per cent). A water bodies occupy 630 ha. area (6 per cent) and the Fallow land occupies 650 ha (7 per cent) but well-developed dendritic drainage pattern and good water availability is in the Sambar watershed.

\section{Introduction}

Land use/land cover knowledge is an important for many planning and management events and it is considered as necessary component for modelling and understanding the earth as system (Yashwant Singh, 2015). Land cover maps are currently being developed form a local to national to global scales. For land use /land cover mapping, panchromatic, medium scale arial images and satellite images have been used. The term of land cover relates to the type of object present on the earth surface. Agricultural fields, Water bodies, Forested areas, and Orchards are related to the land cover and Buildings, structures, highways or any other constructions are the type of the land use. 
Thereby the term of land use land cover is very important for understanding the land utilization pattern.

Remote sensing and GIS based land use and land cover mapping has been carried out by number of scientists, scholars and for different landscapes and it is proved to be a very methodical tool for generation of detailed and updated information for characterization of land according to the different land use and land covers (Amna Butt et al., 2015). The recent technology in the Remote Sensing and GIS concluded the utilization of space borne satellite images for extraction different land classes and related features are one the important development in geospatial technology mapping and their periodic monitoring in GIS environment.

Saucer was the first to analyses the usage of land in a map in 1919. In the United Kingdom, a contribution is made to a land use mapping project. Stamp established the notion of land use in 1962. The land should fulfill all of the nation's essential and genuine needs. Land is used for the purposes such as crops, forests, pastures, mining, and transportation, residential, recreational, industrial and commercial (Wawale and Aher, 2015).

Understanding the impact of man's activities on his natural resource base over time requires viewing the Earth from space. Observations of the earth from space provide objective information on human use of the landscape in instances of rapid and generally unrecorded land use change. Data from Earth sensing satellites has been increasingly important in mapping the Earth's features and infrastructures, managing natural resources, and analyzing environmental change in recent years (Sreenivasulu et al., 2013). For this study, based on picture interpretation experiments with limited checks, three thematic maps were created, including location, false color composite, and land use and land cover maps. Built-up land, Agricultural land, forest land, water bodies, fallow land, barren land are the basic groups that make up the land use-land cover pattern. The amount of land covered by forest is decreasing as a result of human activities. Similarly, the amount of land used for agriculture is reducing. However, the amount of land under urbanization is expanding. The recent activities of real estate agents and property promoters have resulted in a severe disaster in forest and agricultural land. This is a dangerous position in terms of land management. In this setting, land use and land cover change detection investigations are critical for understanding the current situation and planning for the future. In view of this the general land use / land cover pattern of Sambar watershed area were identified using remote sensing database.

\section{Materials and Methods}

\section{Study Area}

The study area is located in the Godavari and Purna basin in Parbhani Tehsil. The watershed is lies between $19^{\circ} 35^{\prime} 78.78^{\prime \prime} \mathrm{N}$ and $76^{\circ} 87^{\prime} 88.44^{\prime \prime} \mathrm{E}$ in the Parbhani district of Marathwada region in Maharashtra. It is located in $16 \mathrm{Km}$ towards North from the district headquarter Parbhani. The elevation/altitude is 414 meters above the sea level. The temperature in summer season goes up to $42^{\circ} \mathrm{C}$ and $11^{\circ} \mathrm{C}$ in winter season. The relative humidity in the southwest monsoon season is high, ranging from $60 \%$ to $80 \%$. In the summer which is the driest part of the year the relative humidity, especially in the afternoons, is less than $30 \%$. The crops are grown in Kharif and Rabi agricultural seasons. In the area of watershed, Kharif Season is most predominant over the Rabbi Season because most of the crops are grown in Kharif season. Jowar, Cotton, Groundnut, Mung, and 
Tur are the main crops grown in Kharif Season. In Rabbi Season, Mostly Wheat, Rabbi Jowar, Turmeric and Gram crops area growing. Shown in fig. 1.

\section{Data use}

In this study, the Survey of India Toposheet No. $56 \mathrm{~A} / 15$ as $1: 50,000$ scale and Landsat 8 satellite imageries used for classifying the land features with the help of the georeferenced toposheet. The ArcGIS 10.8 software was used for data manipulation, compilation and generating the land use and land cover map.

The assign projection system was Universal Transverse Mercator (UTM) WGS 1984 datum and spheroid System. ArcGIS 10.8 software was used to extract the drainage network and watershed boundary from the digital elevation model. Google Earth was also used as reference to visually inspect the ridge and boundaries Table 1 has detail about DEM and Toposheet.

\section{Data Pre-processing}

Image pre-processing is the important process for the land use/land cover mapping. In image processing removes the unwanted distortion, inaccuracies present in satellite imageries, correct the geometric corrections, filtering the images, enhancing the image quality and increase the pixel brightness.

\section{False Colour Composite Image}

After the pre-processing the satellite image the next step is select the select the appropriate band composite. The False colour composition is very popular band to identifying the vegetation and other features. The false colon image is representing the red, green and blue colour for determine the classes. Various feature on the satellite imageries were identified by selecting the different training samples in the false colour composite image.

\section{Land Use and Land Cover Classification}

There generally two methods for the image classification in ArcGIS 10.8 Software namely unsupervised classification and Supervised classification. For this research the supervised classification method was used for identifying the training sample. In the supervised classification collect the few training samples of each class and then merge the sample with the help of "Merge tool". Providing the suitable class name and use the appropriate colour for the classes. After that signature file saved.

\section{Identification of training samples}

The training set is identified through a supervised classification process. The identified training samples namely the Agricultural land, Water bodies, Barren land, Urban area, Forest land, and Fallow land.

\section{Results and Discussion}

\section{Land Use/Land Cover Classification}

\section{Agricultural Land}

The agricultural land is mainly demarcated as the land use primary for the food and fibre. Agricultural land represents the cultural activities, cropping pattern will be distinctive on the land surfaces. It includes the cropland and pasture land, orchard crops, groves, horticultural land.

After the analysis, area under the agricultural land $43 \%$ (4135 ha) has been found. Mostly. Jowar, Cotton, Groundnut, Mung, and Tur are the main crops grown in the Sambar watershed. The economy of the peoples in Sambar watershed is mainly depends on the agriculture. 


\section{Barren Land}

The barren land is the land which is limited ability to support the life and vegetation and contain the limited biodiversity. Mostly barren land contains the area of sand and rocks on which agricultural activities does not take place, vegetation present on this land as a thin layer in the form of shrub and brush categories. Barren land contains the area of dry salt, flat beaches, sandy areas, mines, gravel pits. The Sambar watershed, $35 \%$ that is about $3921 \mathrm{ha}$. area is under the barren land. Most of the barren area in a watershed is North, and North-west side because of the area on these sides has rocky surface and vegetation in the form of shrubs and shrubs. Water availability is very low that portion.

\section{Water bodies}

The water bodies are defined as the naturally or artificially water body with the presence of the surface water during the most of the years. Water is the important natural resource on an earth and it can find in a various form on earth such as the river, streams, channels, ocean, lake, farm ponds etc. water is the essential source for human lives and the irrigation purpose.

In a Sambar watershed it was noticed that the most of the water bodies area cover by the streams and small canals. The total $6 \%$ i. e. (630 ha) area occupied by the water bodies. The watershed has good ground water potential in southern region.

Table.1 Data used for watershed delineation

\begin{tabular}{|c|c|c|c|}
\hline $\begin{array}{c}\text { Sr. } \\
\text { No. }\end{array}$ & $\begin{array}{c}\text { Type of } \\
\text { Data }\end{array}$ & Detail & Source \\
\hline $\mathbf{1}$ & SOI & Toposheet No. E43E15 & Nakshe Portal \\
& Toposheet & $(56$ A/15) & www.usgs.earthexplorer.gov.in \\
\hline $\mathbf{2}$ & Landsat 8 & Landsat Collection & \\
& Satellite & 1 Level -1 & \\
& Image & Landsat 8 OLI/TIRS C1 & \\
& & Level- 1 & \\
& & LC81450472203006LGN00 & \\
& & Category- T1 & \\
& & WRS Path- 145 & \\
& & WRS Row- 047 & \\
& & Date $-01 / 11 / 2020$ & \\
\hline
\end{tabular}

Table.2 Area Under the Different LULC Classes

\begin{tabular}{|c|c|c|c|c|}
\hline Sr. No. & Name & Area (Ha) & Area (Sq. Km) & Percentage (\%) \\
\hline $\mathbf{1}$ & Agricultural land & 4135 & 41.35 & $43 \%$ \\
\hline $\mathbf{2}$ & Barren land & 3392 & 33.92 & $35 \%$ \\
\hline $\mathbf{3}$ & Waterbodies & 630 & 6.30 & $6 \%$ \\
\hline $\mathbf{4}$ & Fallow land & 650 & 6.5 & $7 \%$ \\
\hline $\mathbf{5}$ & Forest area & 502 & 5.02 & $5 \%$ \\
\hline $\mathbf{6}$ & Urban area & 390 & 3.9 & $4 \%$ \\
\hline Total & & $\mathbf{9 6 9 9}$ & $\mathbf{9 6 . 9 9}$ & $\mathbf{1 0 0} \%$ \\
\hline
\end{tabular}


Fig.1 Location of Study Area

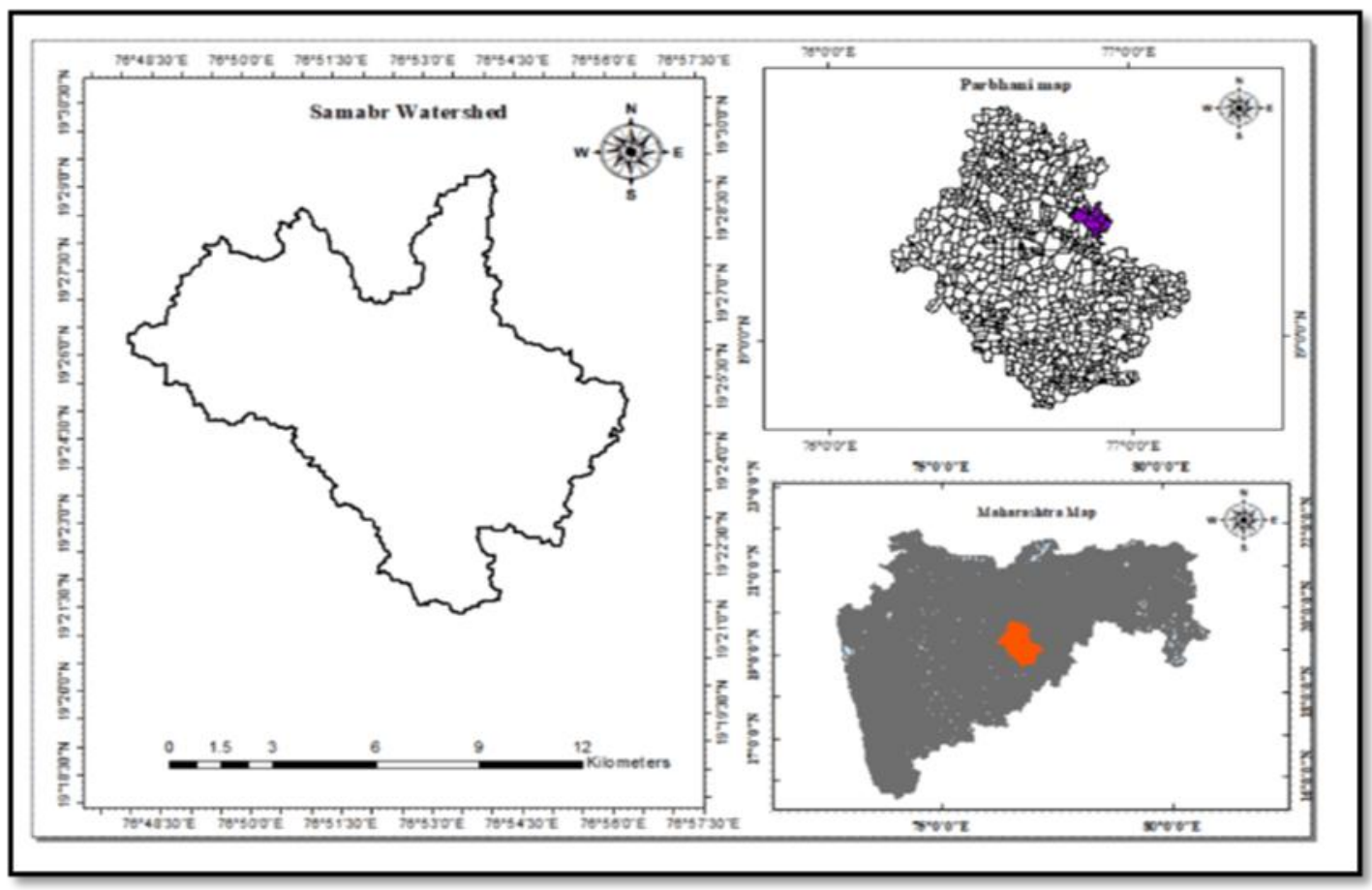

Fig.2 Natural Colour Satellite Image

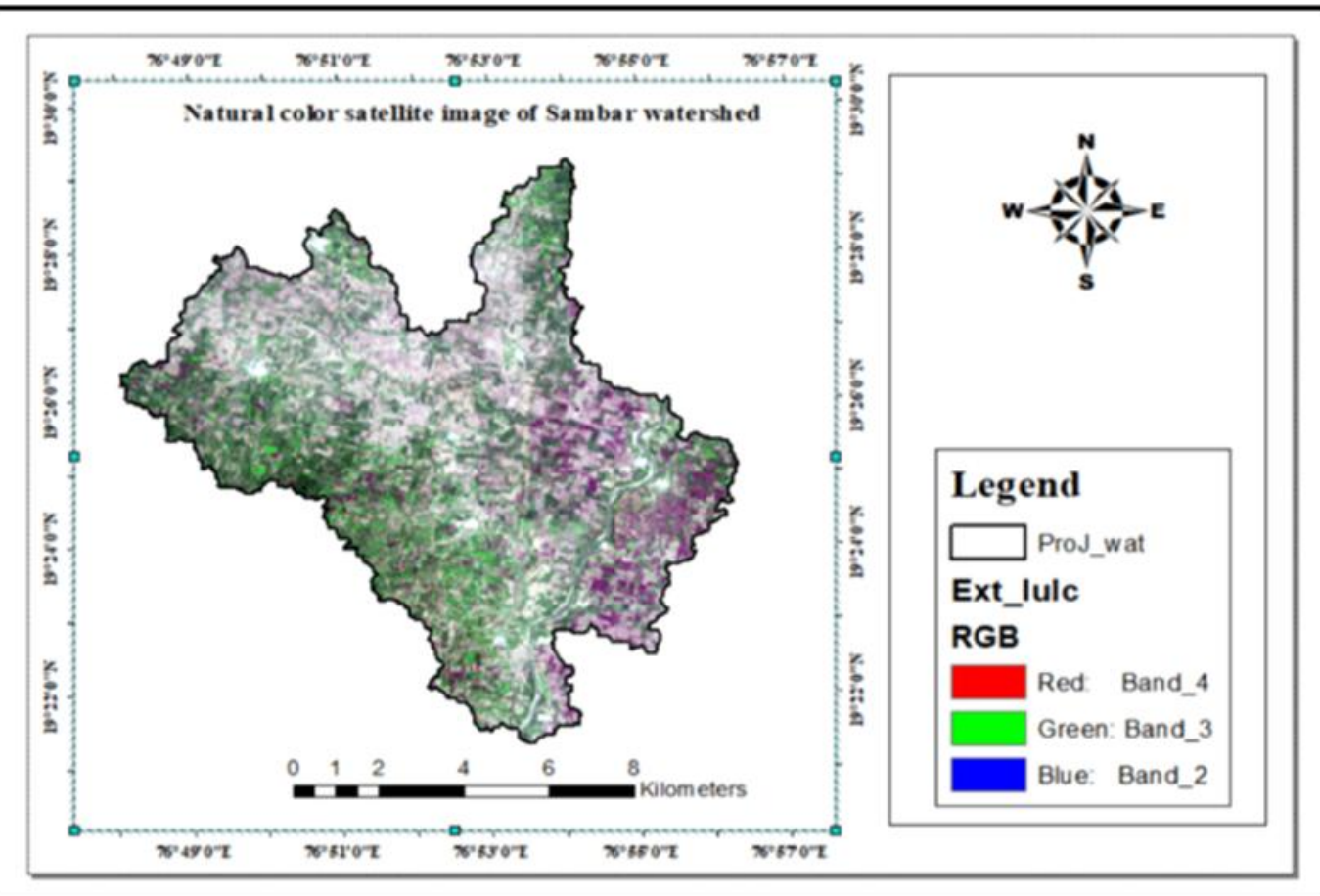


Fig.3 False Colour Composite Image

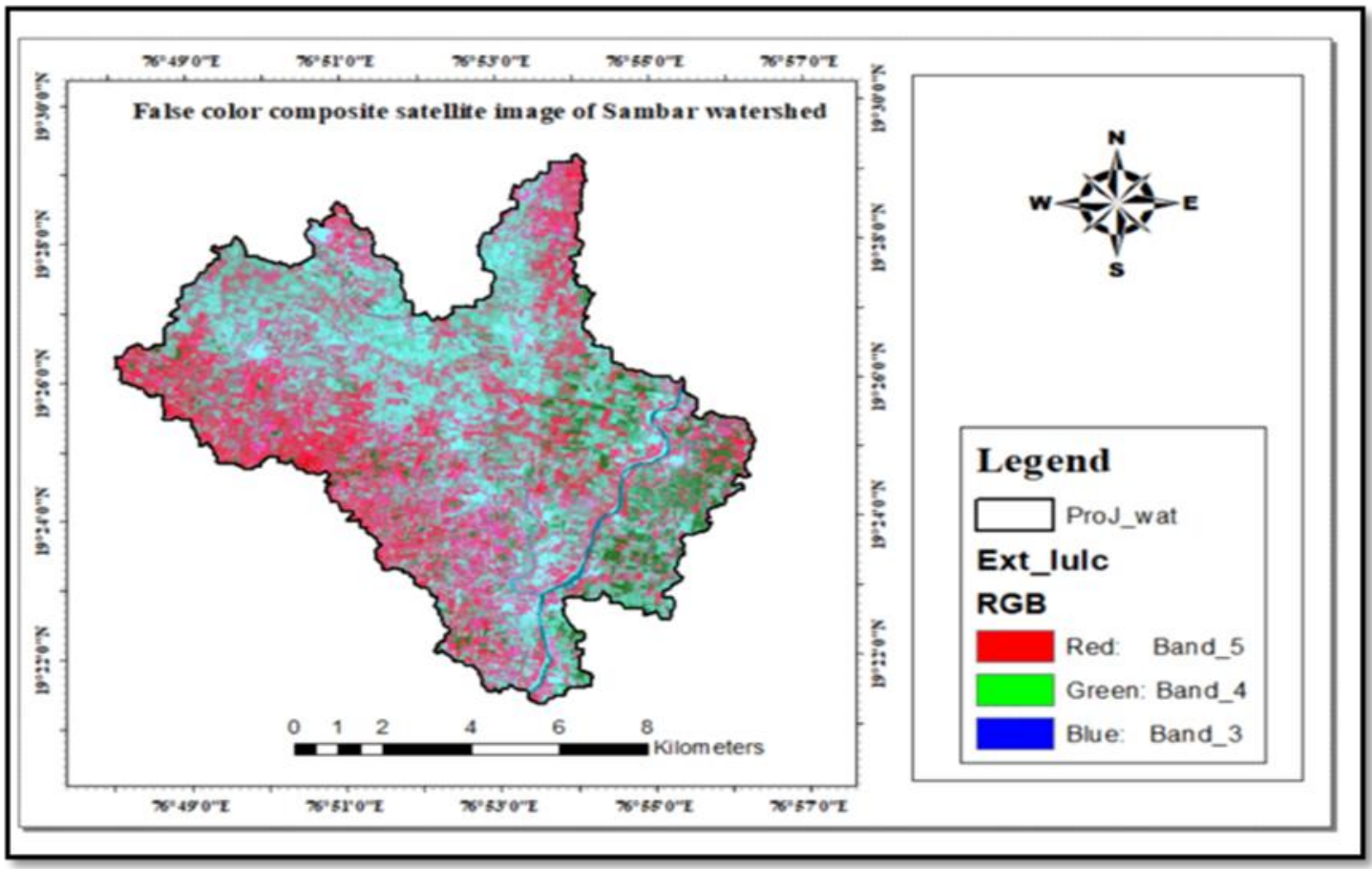

Fig.4 Final Land Use/Land Cover Map for Sambar Watershed

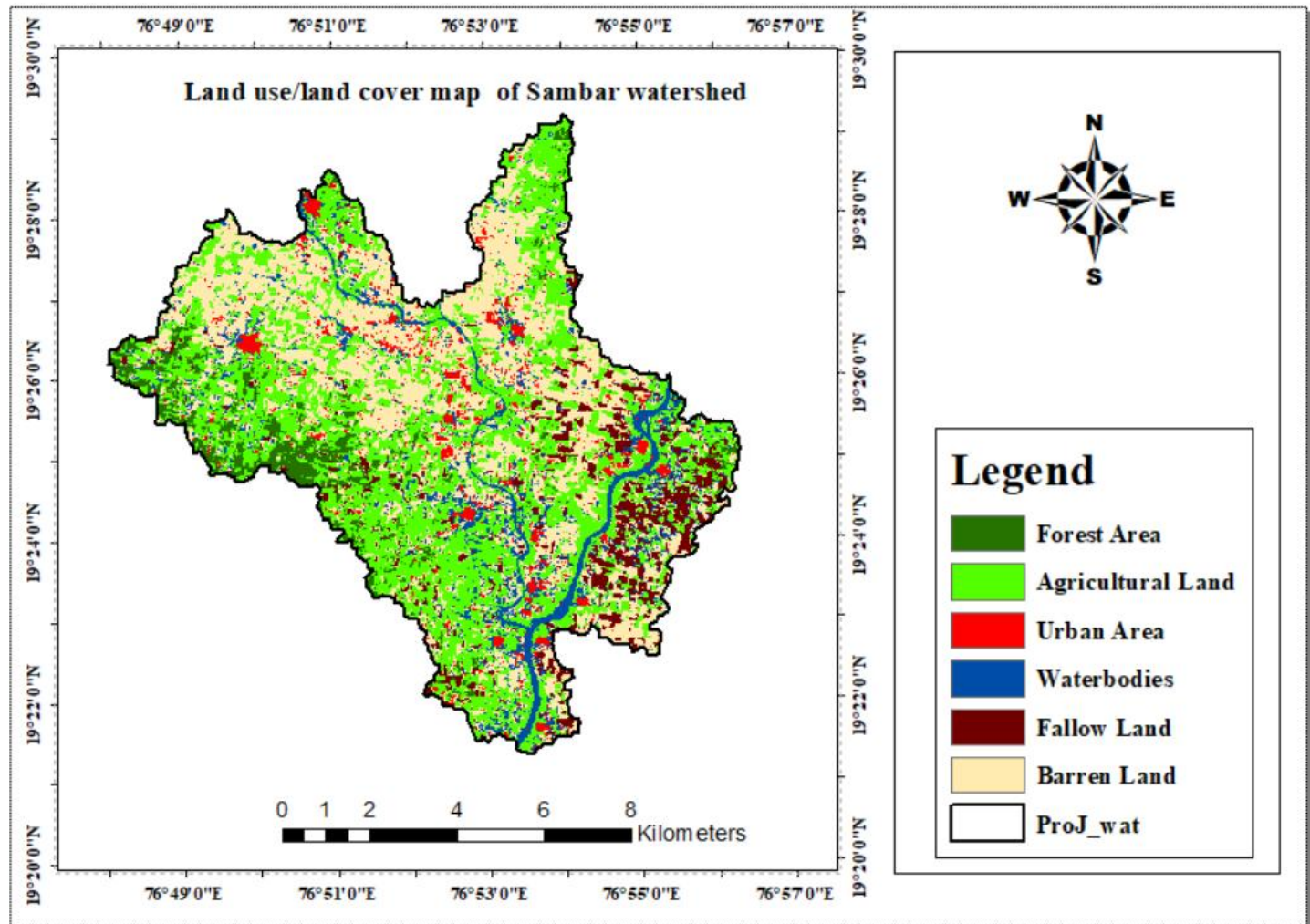


Pie Chart.1 Land use/land cover classification

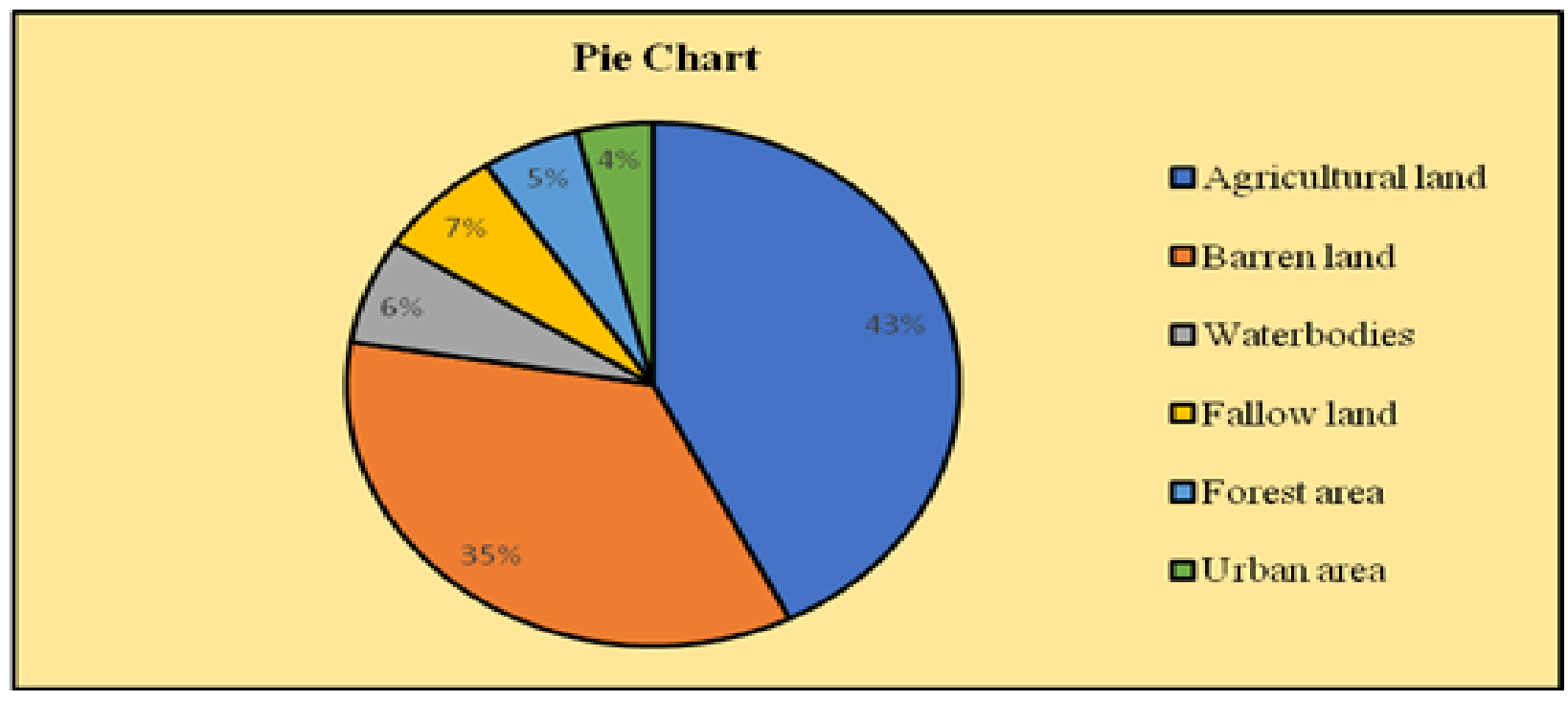

The Sambar watershed has classified as per the major land use/land cover types. The Landsat 8 satellite data and Geographical Information System techniques were used to identify the land use categories such as Builtup lands, Agricultural lands, Forest lands, Water bodies, Barren lands and Fallow land. The Landsat 8 Satellite images used for analysing land use and land cover pattern. With the help of Geographic Information System, the various land use and land cover zones are mapped, which in turn helps for decision maker for planning purpose. The Agricultural lands are well distributed throughout the watershed area and it covers 4135 ha. (43 per cent). Forest occupies 502 ha area and sharing about 5 per cent of the total land use land cover of the study area. The Urban land occupies 390 ha. area (4 per cent) and there was a rapid expansion of settlement area. Barren land occupies 3392 ha. area (35 per cent). A water bodies occupy 630 ha. area (6 per cent) and the Fallow land occupies 650 ha (7 per cent) but well-developed dendritic drainage pattern is there in the Sambar watershed.

\section{References}

But A., Shabbir R., Sheikh S. A., Aziz Neelam., 2015. Land use change mapping and analysis using remote sensing and GIS: A case study of Simly watershed, Islamabad, Pakistan. Egyptian Journal of Remote Sensing and Space Science, (18) 2.

Karwariya S. \& Goyal S., (2011). Land use and land cover mapping using digital classification technique in Tikamgarh district, Madhya Pradesh, India using remote sensing. International Journal of Geomatic and Geoscience, Volume 2, No. 2, ISSN 0976-4380.

Mishra A., Karwariya S., Goyal S., (2012). Land use/land cover mapping of Chhatarpur district Madhya Pradesh, India using unsupervised classification technique. IOSR Journal of Engineering, Volume 2, Issue 10 (October 2012) pp. 51-56, ISSN 22788719.

Pandey A. C. \& Nathawat M. S., (2006). Land use/land cover mapping through digital image processing of satellite data: case 
study from Panchakula, Ambala and Yamuna Nagar district of Haryana state. Journal of Remote Sensing and Environmental Science. Vol. 3, pp. 5568.

Pandey A. C. \& Nathawat M. S., (2006). Land use/land cover mapping through digital image processing of satellite data: case study from Panchakula, Ambala and Yamuna Nagar district of Haryana state. Journal of Remote Sensing and Environmental Science. Vol. 3, pp. 55-
68.

Rujoju-Mare M., Andrei M. 2016, Mapping land cover using remote sensing data and GIS techniques: A case study of Prahova Subcarpathian. Procedia Environmental Sciences 32244 - 255. Sreenivasulu G., Jayaraju N., Kishore K., Prasad T. L., 2014. Land use and land cover analysis using remote sensing and GIS: Case study in and around Rajampet, Kadapa district, Andhra Pradesh, India.

\section{How to cite this article:}

Varpe Shriniwas, B. and Payal Sandip, D. 2021. Land Use/Land Cover Mapping of Sambar Watershed by Using Remote Sensing and GIS. Int.J.Curr.Microbiol.App.Sci. 10(09): 578-585. doi: https://doi.org/10.20546/ijcmas.2021.1009.066 